\title{
HSF1 wt Allele
}

National Cancer Institute

\section{Source}

National Cancer Institute. HSF1 wt Allele. NCI Thesaurus. Code C71422.

Human HSF1 wild-type allele is located in the vicinity of $8 \mathrm{q} 24.3$ and is approximately $23 \mathrm{~kb}$ in length. This allele, which encodes heat shock factor protein 1, is involved in the transcriptional regulation of genes that are involved in the cellular response to thermal stress. 